\title{
Basic characteristics of test model and determine the optimum pole number of In-Wheel SR Motor for Electric Buses considering torque weight ratio
}

\author{
H. Sato, H. Goto, and O. Ichinokura \\ Graduate School of Engineering, Tohoku University, 6-6-05 Aoba Aramaki Aoba-ku, Sendai 980-8579, Japan
}

\begin{abstract}
Electric vehicles have recently attracted attention as future generation cars. It is especially important to have electrically driven heavy vehicles such as buses and trailers that have little environmental influence. Switched reluctance (SR) motors have no magnets. This means they have no thermal demagnetization, are inexpensive to manufacture, and have excellent mechanical strength. These advantages are suitable for application to the In-Wheel SR motors of electric vehicles. We developed in-wheel SR motors for heavy vehicles and carried out a proof load test on them.
\end{abstract}

Key words: electric vehicle, electric bus, switched reluctance motor, in־wheel type, outer-rotor

\section{トルク重量比を考慮した電気バス用インホイール SR モータの最適極数の決定 と試作機の基礎特性}

佐藤宏樹・後藤博樹・Dノ倉理

東北大学 大学院工学研究科, 仙台市青葉区荒巻字青葉 6-6-05（率980-8579）

\section{1. はじめに}

従来の内燃機関自動車の排出ガスに含まれる二酸化炭素 や窒素酸化物による地球環境問題, その燃料として使用さ れる化石然料の枯渇問題が深刻化している 1). そのため, 直接化石燃料を使用せず，排出ガスがない，クリーンな電 気自動車が注目されている，近年，普通乗用車タイプの電 気自動車においては大量生産が開始され，急速に普及が始 まりつつある. 一方で，バスやトレーラ等，1 台当たりの 環境負荷が大きい大型自動車については, 電動化の検討が なされているものの十分ではない. 特に, 現代の自動車依 存性社会では, 車両の絶対数の増加に伴う交通渋滞や事故 が社会問題化しており, バスなどの公共機関の利用の促進 が望まれているため, バスの電動化は重要な課題である.

電気自動車の駆動方式の一つとして，モータをホイール 内部に設置し, 減速機を介さずにホイールを直接駆動させ るインホイールダイレクト駆動方式がある.この駆動方式 では，減速ギア等の伝達損失が軽減できるほか，車体レイ アウトの自由度向上に伴い車内空間の有効利用が可能とな り，バスにおいては身障者や高齢者に考慮した低床レイア ウトが期待される。また，各輪独立駆動による高度な運動 制御が可能となり, バスや大型トレーラの運動性能の向上 に寄与できる，一方で，モータの体積はホイール内に格納 できる大きさに制限されることや，ばね下重量が重くなる ことにより, 路面追従性が悪化して乗り心地が悪くなるな どといった問題点がある. そのため，モータに関してはさ らなる小型化, 軽量化が必要となる.

筆者らはインホイールダイレクト駆動用モータとして優 れた特性を持つ SR モータに着目しており，実際にインホ イール SR モータを開発し，小型自動車に搭載して走行実
験を行っている 2)-5). 国内の電気自動車用 SR モータの研究 としては, 鉄心材料の検討や固定子極の根元の形状を変化 させるなどの検討により，市販ハイブリッド自動車搭載の 埋込磁石同期モータと同等の体積トルク密度を実現し, 効 率についても 95\%を超える実験結果が示されている ${ }^{6)}$ が, インホイールモータでは, 体積トルク密度に加えて, トル ク重量密度が重要となる。また, ロータ内の磁気回路を分 割するセグメント構造によってトルクを増加できるという 研究結果が示されている 7),8). しかし, セグメント型 SR モ 一タでは, 全節巻であることからコイルエンドが大きくな ってしまいインホイールモータのような扁平なモータに適 さない. 本稿では, 電気バス駆動用大型インホイール SR モ 一タについて, 多極化による性能の向上と軽量化を目的と して, 有限要素法（FEM）を用いた解析により，極数の検 討を行った，その際，インホイールモータへの適用性の評 価として，トルク重量密度について検討し，最適な極数を 決定した。その結果に基づき，実際にインホイール SR モ 一タを設計・試作を行い，基礎特性の測定を行ったので報 告する。

\section{S Rモータ}

$\mathrm{SR}$ モータは，回転子・固定子ともに突極構造を有し，固 定子巻線からみた磁気回路の磁気抵抗変化によるリラクタ ンストルクを利用したモータである 9)-11)。このモータは固 定子，回転子ともに珪素鋼板を打ち抜いたものを積層して 製作し，巻線は固定子に集中巻され，回転子には巻線や磁 石を有しない，そのため，構造が簡単で機械的強度に優れ ており, 磁石が不要なことから熱による減磁の心配もなく, ネオジムなどの希土類金属を使用しないため, 安価である. 
さらに，回転子に巻線がないため，回転子銅損がなく，誘 導電動機よりも高効率が期待できるといった優れた特長を 有しており, インホイールモータに適したモータであると 考えられる.

次に, SR モータの動作原理について説明する. 図 1 は 最も単純な励磁方法であるシングルパルス駆動を行った場 合における，インダクタンス，相電圧，相電流波形を表し た模式図である。ここで， $\theta$ は固定子に対する回転子の位 置を示す. 図 1 に示したように, インダクタンスカーブは 回転子極と固定子極が対向した位置で最大となり, 非対向 位置で最小となっている.

ここで，鉄心の磁気特性が線形であると仮定した場合， $k$ 相固定子から見たインダクタンスを $L_{\mathrm{k}}(\theta)$ として,$k$ 相のト ルク $\tau_{\mathrm{k}}$ は次の様に表される.

$$
\tau_{k}=\frac{1}{2} i_{k}^{2} \frac{d L_{k}(\theta)}{d \theta}
$$

(1)式から SR モータのトルクの向きは電流の向きには よらず，インダクタンスの回転子位置に対する傾きにより 決定される.インダクタンスの傾きが正の時，すなわち， 回転子が非対向位置から対向位置に向からタイミングで電 流を流すことにより回転方向に有効なトルクを発生させる ことができる.

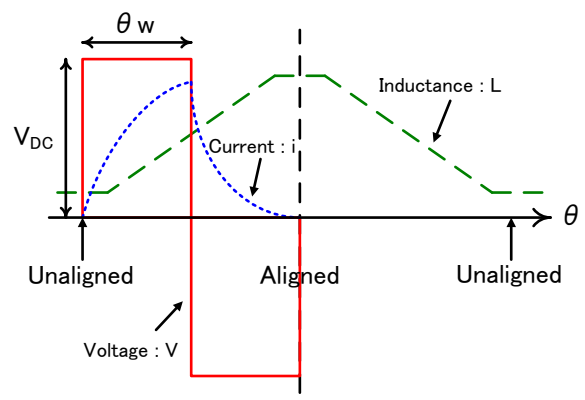

Fig. 1 Relationship between inductance, and phase voltage, phase current for different rotor positions.

\section{3. 電気バス用S Rモータの極数に関する検討}

今回電気バス用 SR モータを設計するにあたり，要求性 能として, 図 2 に示す走行性能曲線を用いて説明する。今 回の仕様として, 巻線の温度上昇を考慮して算出した連続 許容電流密度である $7 \mathrm{~A} / \mathrm{mm}^{2}$ で勾配 $10 \%$ の坂を時速 $60 \mathrm{~km} / \mathrm{h}$ で走行可能であること, 同じく最大 1 分間の短時 間許容電流密度である $10 \mathrm{~A} / \mathrm{mm}^{2}$ で勾配 $15 \%$ の坂を時速 $40 \mathrm{~km} / \mathrm{h}$ で走行可能であることを設計目標としている。ま た，この走行性能曲線については設計車両とほぼ同じ大き さである日野ポンチョのものを参考に計算している，設計 指標を満たすモータを製作するために, 最適な極数の組み 合わせに関して, SR モータの極数決定式である(2)式を用 いていくつかの極数のモータを解析 ・ 比較し, 最適な極数 の検討を行った ${ }^{12)}$. ここで, $P_{\mathrm{r}}$ は回転子極数, $k$ は相数, $P_{\mathrm{s}}$ は固定子極数をそれぞれ示している.

$$
P_{r}=P_{s}\left(1 \pm \frac{1}{k}\right) .
$$

(2)式より, 1 つの固定子極数の值に対して 2 つの回転子極 数を定めることができることがわかる. 今回, 駆動回路の コストや配線数を考慮して, 駆動相数 $k=3$ としている. 以 上の条件を踏まえ, 固定子極 12 極・回転子 8 極の $12 / 8$ モ デル，同じく固定子極 24 極・回転子極 16 極の $24 / 16$ モデ ル, 固定子極 30 極・回転子 20 極の $30 / 20$ モデルの 3 つの モデルについて FEM を用いて解析を行った. 解析は, 汎 用磁界解析ソフトである JMAG Studio を用いた。 各モデ ルの諸元について，12/8 モデルを図 3 に，24/16 モデルを 図 4 に，30/20 モデルを図 5 にそれぞれ示す. 各モデルに おいて, 外径, 積厚, ギャップ長, 固定子極長を同一とし ている.

それぞれのモデルにおける電流密度一トルク特性の解析 結果を図 6 に示す。図 6 より, 低電流密度領域においては どの極数のモデルでもほぼ同一の特性を示している。しか し，高電流密度領域においては，24/16 モデルが最も高い トルク特性を示していることが明らかになった.また, $12 / 8$ モデルと $30 / 20$ モデルについて比較すると, 電流密度が $15 \mathrm{~A} / \mathrm{mm}^{2}$ までは $30 / 20$ 極モデルの発生トルクが大きいが, $15 \mathrm{~A} / \mathrm{mm}^{2}$ 以上では $12 / 8$ モデルの方が大きなトルクを発生 していることが確認できる。これは多極機では極間距離が 短いため, 磁束密度が高くなると, 固定子極間の漏れ磁束 が大きくなることが原因と考えられる.

次に，ばね下重量への影響を考慮するため，各モデルに ついて, トルクー重量比を比較したものを図 7 に示す. 卜 ルク一重量比は, 各電流密度における発生トルクを各 SR モータの重量で割ることにより算出している. 図 7 では, 7 $\mathrm{A} / \mathrm{mm}^{2}, 10 \mathrm{~A} / \mathrm{mm}^{2}, 14 \mathrm{~A} / \mathrm{mm}^{2}$ におけるトルク重量比を示し た.

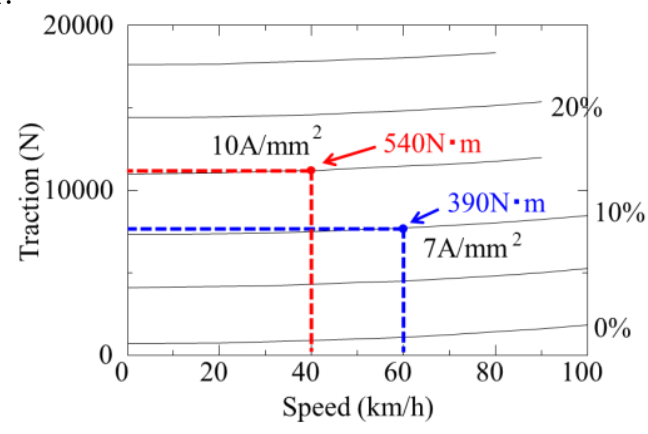

Fig. 2 Travelling performance curve.

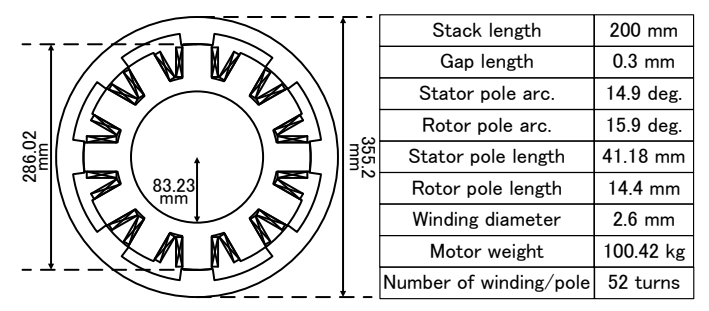

Fig. 3 Schematic of $12 / 8$ SR motor. 


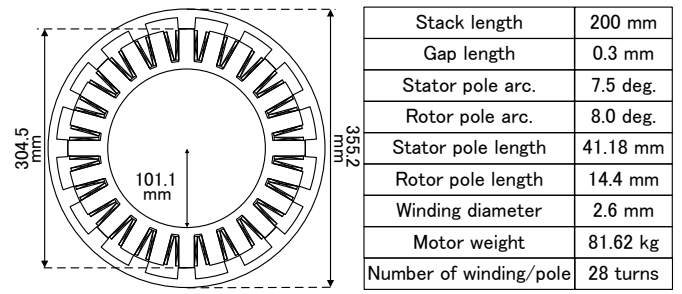

Fig. 4 Schematic of 24/16SR motor.

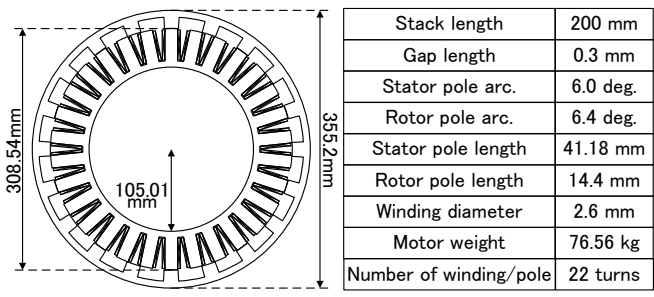

Fig. 5 Schematic of 30/20SR motor.

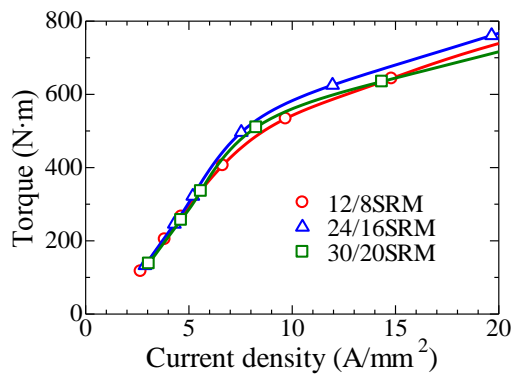

Fig. 6 Current density vs. torque characteristics.

同じように， $7 \mathrm{~A} / \mathrm{mm}^{2}$ は連続許容電流密度， $10 \mathrm{~A} / \mathrm{mm}^{2}$ を 最大 1 分間の短時間許容電流密度, そして $14 \mathrm{~A} / \mathrm{mm}^{2}$ は最大 30 秒間の瞬時許容定格電流密度として想定した. 図 7 より, いずれの電流密度においても, トルク一重量比は $12 / 8$ モデ ルが最も小さく, 30/20 極モデルが最も大きくなることがわ かる．前述したように，トルクの值そのものは，24/16 モ デルが 30/20 モデルに比較して大きいが，極数が多くなる につれて，各極を通過する磁束が分散されるため，ヨーク を細くできることに伴い重量を軽くなるため,このような 結果となったと考えられる.

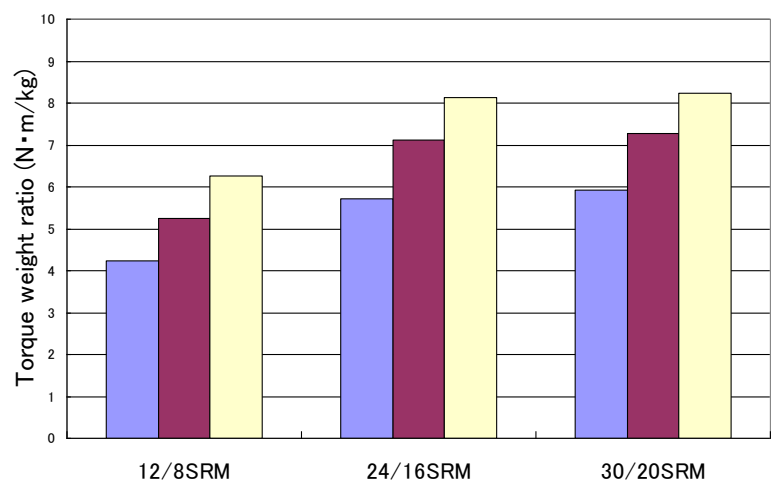

Fig. 7 Torque-weight ratio.

\section{4. 電気パス用S Rモータの試作と基礎特性の測定}

\section{1 電気パス用SRモータの試作}

インホイールモータとして設計を行う場合に，小型で高トルク であることはもちろんのこと, 軽量であることも重要視される. そこで, トルクの面で比較的高い性能を示し, トルク一重量比に おいて最も高い值を示している 30/20 極モデルをもとに電気バス 用インホイール SR モータを製作した．実際に試作した 30/20 極 の電気バス用インホイール SR モータの諸元を図 8 に示す。図 8 と図 5 の諸元を比較すると，積厚とギャップ長については同一と しているが，巻線を丸線から角線に変えたことにより，巻線占積 率を向上し, 巻数およびモ一夕重量, 固定子極長が変更されてい る. また，機械的強度を確保するために，固定子ヨークおよひ回 転子ヨークに直径 $3.2 \mathrm{~mm}$ の固定用の穴を開けている. FEM を用 いてこのモータの定常解析を行い，実際に試作したモ一タを用い て，電流密度一トルク特性を測定して比較を行った.

ここで，試作モータと試験装置を図 9 に示寸。試作モ一夕は最 大負荷卜ルク $1200 \mathrm{~N} \cdot \mathrm{m}$ のパウダーブレーキ・トルクメータ一体型 負荷装置に対し，チェーンカップリングを用いて接続されている. 本 SR モータはインホイールモータであり, 通常は回転軸を持たな いため，測定用に新たに回転軸を製作・設置した．駆動回路はSR モータで一般に用いられている非対称ハーフブリッジコンバータ を製作したが，パワーデバイスの定格電流が小さいため，直流電 源装置の電流リミッタが働かない範囲での負荷試験を行った.

モータの制御は，モータに取り付けたリラクタンス型ブラシレ スレゾルバからの位置情報を取得し, FPGA により回転子位置に 応じたゲート信号を生成している，なお，電源電圧は $50 \mathrm{~V}$ 一定と し，負荷トルクを約 $10 \sim 130 \mathrm{~N} \cdot \mathrm{m}$ まで変化させ，それぞれの場合 における平均機械出力, 電流・電圧波形を測定し, 1 周期あたりの 電流実効值を求め, 電流密度一トルク特性を求めた. また, 比較 のため, FEM の巻線抵抗值は試作機の $\mathrm{u}$ 相, $\mathrm{v}$ 相, $\mathrm{w}$ 相の巻線抵 抗をそれぞれ測定した值を適用している.

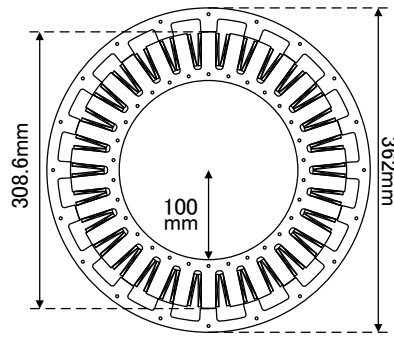

\begin{tabular}{|c|c|}
\hline Stack length & $200 \mathrm{~mm}$ \\
\hline Gap length & $0.3 \mathrm{~mm}$ \\
\hline Stator pole arc & $6.0 \mathrm{deg}$. \\
\hline Rotor pole arc & $6.4 \mathrm{deg}$. \\
\hline Stator pole length & $41.3 \mathrm{~mm}$ \\
\hline Rotor pole length & $14.4 \mathrm{~mm}$ \\
\hline Sectional area & $3.6 \mathrm{~mm}^{2}$ \\
\hline Motor weight & $91.43 \mathrm{~kg}$ \\
\hline Number of windings/pole & $40 \mathrm{turns}$ \\
\hline
\end{tabular}

Fig. 8 Schematic of prototype model 30/20SR motor.

\section{2 実験結果}

速度一トルク特性, 電流密度一トルク特性について, FEM による解析結果と実験による測定值を図 10, 図 11 に それぞれ示す。今回の実験データでは電源に制限があった ため, 定格である $160 \mathrm{~V}$ ではなく $50 \mathrm{~V}$ で実験を行っている. 
図 10, 図 11 から，FEM による解析結果と実験による測定 結果が定性的に一致していることが確認できる. しかしな がら，実験值におけるトルクは，同一速度および電流密度 における解析值よりも 30～40\%程度低くなっているのがわ かる. FEM による解析結果と実験結果の誤差の理由につい て考える.

まず，大きな原因としてモータ内部の機械的損失が，シ ミュレーションで考慮されていないことが考えられる。試 作機は大型のモータであり, 重量も $100 \mathrm{~kg}$ を超えるため, モータを支えるベアリング等の接触部分で発生する機械的 損失も大きいと考えられる.この機械損失の一部について, 実測を行ったので報告する. 今回は電気バス用の比較的大 型のモータであり，機械損失も大きいと考えられるため現 有のサーボモータでは測定は不可能と考え, モータの速度 減衰特性から機械損失の一部を算出した。 具体的にベアリ ング等による機械損失は, ベアリングの転動体の回転摩擦 によるクーロン摩擦と中の油部分の粘性摩擦の 2 種類に分 けられる. クーロン摩擦は回転数によらず一定值をとり, 粘性摩擦は回転数に依存するという性質がある。そこで, モータを低回転数で回転させた状態から電源をオフにする ことによって，回転数が減衰し停止するまでの時間を計測 し, その波形の近似を行い機械損失の一部を算出した. 図 12 に回転数 $115 \mathrm{rpm}$ で実験を行った際の時間一速度減衰特 性を示す. なお, 低回転数の実験のため, 回転数に依存し て大きくなる粘性摩擦に関しては今回は考慮せずに, クー ロン摩擦のみを式(3)から算出した。

$T_{c}=\frac{J}{t}\left(\omega_{0}-\omega\right) \approx 24.15 \mathrm{~N} \cdot \mathrm{m}$

$T_{c}$ はクーロン摩擦, $J$ は慣性モーメント, $t$ は時間, $\omega$ は回 転数を示している．算出したクーロン摩擦による機械損失 は $24.15 \mathrm{~N} \cdot \mathrm{m}$ とかなり大きい值となっており, シミュレー ションとの大きな差異の原因となっていることが分かる. 今後は残りの誤差について実験環境を整備して誤差の測定 を行っていきたい.

一方, 図 13 に示した試作モータの断面図のように, 回転 子位置センサであるレゾルバは, ホイールハブ軸の角度を 検出している. しかしながら, 路面からの衝撃がロータに 直接伝わるのを防ぐため, ホイールハブとロータはゴムカ ップリングにより軟結合されており, 負荷が加わった場合 は，ゴムカップリングが圧縮・伸長し，

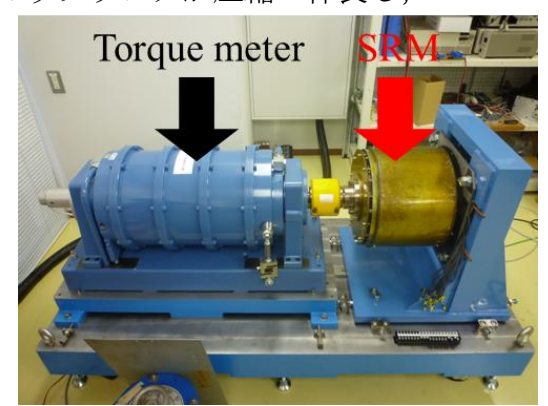

Fig. 9 Prototype model 30/20SR motor and experimental setup.
位相差が生じると考えられる．また，この位相差は，負荷 トルクによっても変化すると考えられる.

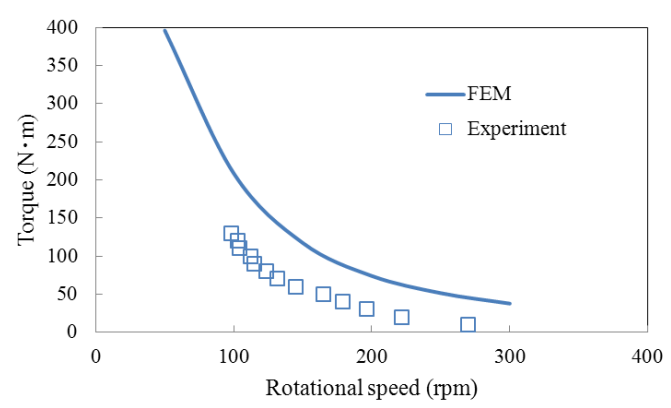

Fig. 10 Rotational speed vs. torque characteristics.

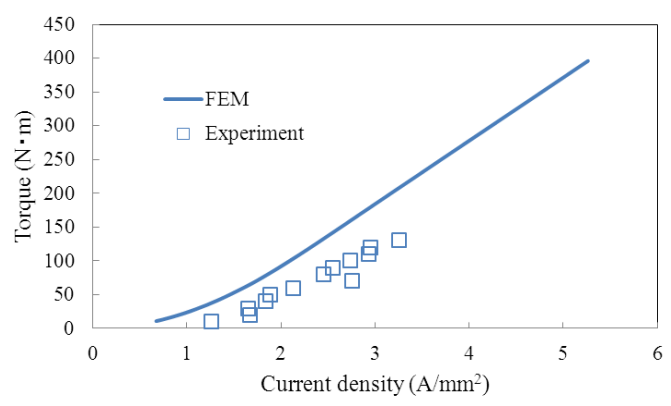

Fig. 11 Current density vs. torque characteristics.

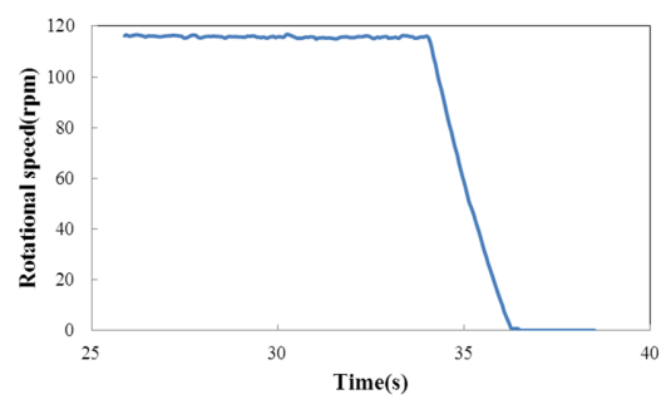

Fig. 12 Time vs. rotational speed characteristics.

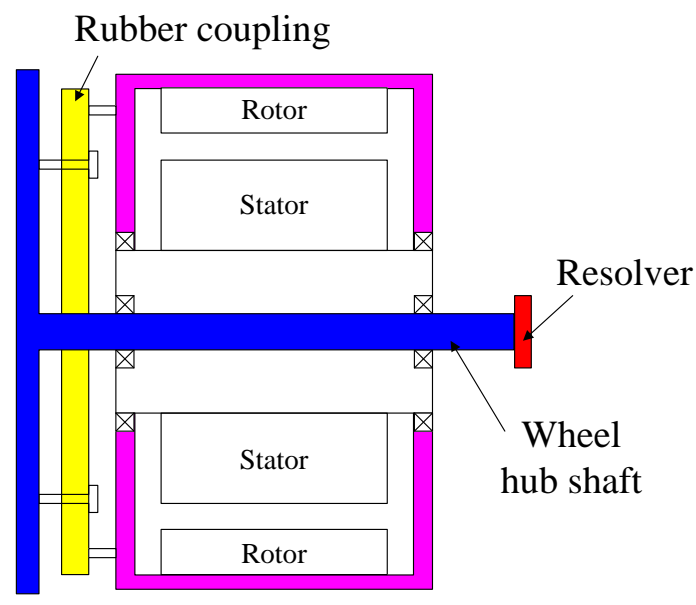

Fig. 13 Cross section of prototype motor.

図 14(a)に FEM 解析による各相の電流波形を，図 14 (b) 
に実測した電流波形を示す。各電流波形は，それぞれ電源 電圧 $50 \mathrm{~V}$, 回転数 $200 \mathrm{rpm}$ の場合のものを示している. 図 14 の 2 つ電流波形を比較すると, 実験で得られた電流值 のピーク值の方が, FEM によるシミュレーション結果の電 流のピーク值よりも 20〜 25A 程度低くなっていることが確 認できる. 電流波形の特徵として, ピーク值が削り取られ てつぶれた波形になっていることから, ゴムカップリング によってレゾルバの検出する回転子位置情報がずれ, 励磁 位相が遅れている可能性が高い. そのため, 今回は効率に 関する検討は行っておらず，今後回転子位置検出の問題が 解消されたのち行っていきたいと考えている。

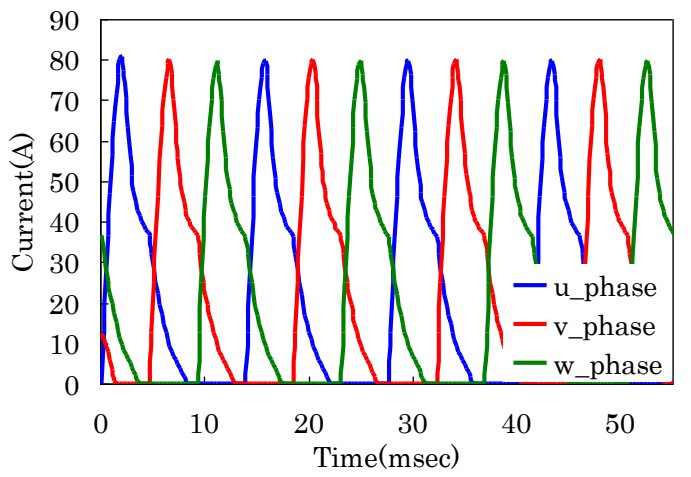

(a) Current waveform in simulation

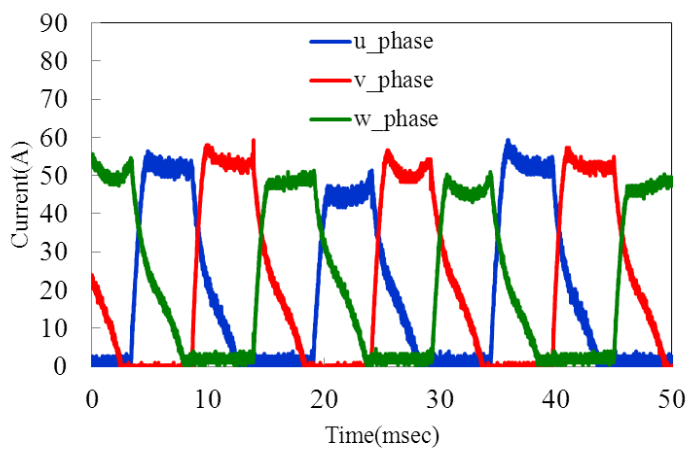

(b) Current waveform in experiment

Fig. 14 Comparison of current waveforms.

\section{5. まとめ}

本稿では，まず，電気バス駆動用インホイール SR モー タの最適な極数の検討について報告した.

また，その結果から，試作モータを製作して速度一トルク 特性, 電流密度一トルク特性を計測し, シミュレーション との比較検討を行った.
極数に関する検討では, 発生トルクで比較した場合 24/16 モデルが最も良い特性を示したが, トルク一重量比で比較 した場合においては 30/20 モデルが最も高い特性を示した. インホイールモータでは軽量であることも要求されること から，試作を行うにあたって極数は 30/20極とした。

また，試作モータについて，基礎的な実験を行い，実験 值と FEMによるシミュレーション值の比較を行った結果, FEM によるシミュレーション值と実験值が定性的に一致 していることが確認できた。しかし，実験值はシミュレー ション值よりも 30〜40\%程度低い特性を示しており，原因 として, 機械損が大きいことや回転子位置検出精度の低下， シミュレーションでは駆動回路での損失を考慮していない 等の原因が考えられる.

今後は，機械的損失を計測する手法や，回転子位置検出 精度の改良を行うとともに，回路損失を考慮するなど，シ ミュレーション精度の向上を行っていきたい. また，今回 は電源や駆動回路の制限により，定格電圧・定格負荷に対 して，低電圧・低負荷での測定であったが，今後，電源お よび駆動回路を整備し, 定格電圧・定格負荷での測定・検 討を行っていきたい.

\section{References}

1) H. Shimizu: Denki Jidousha no Subete (in Japanese) (Nikkan Kougyo Shinbnsha, Tokyo, 1995).

2) H. Goto, Y. Suzuki, K. Nakamura, T. Watanabe, H. J. Guo, and O. Ichinokura: Journal of Magnetism and Magnetic Materials, 290-291, 1338 (2005).

2) T. Suzuki, K. Saito, T. Watanabe, H. J. Guo, O. Ichinokura, and S. Kikuchi: J. Magn. Soc. Jpn., 25, 1211 (2001).

4) Y. Suzuki, K. Nakamura, and O. Ichinokura: The paper of technical meeting on Magnetics, IEEJ, MAG-03-113 (2003).

5) A. Nishimiya, H.Goto, H. J. Guo, and O. Ichinokura: J. Magn. Soc. Jpn., 32, 487 (2008).

6) M. Takeno, N. Hoshi, A. Chiba, M. Takemoto, S. Ogasawara : The papers of Technical Meeting on Vehicle Technology, IEE Japan 2011(14), 53-58, 2011-03-24

7) Y. Matsuo, T. Higuchi, T. Abe, Y. Miyamoto, M. Ohto : The papers of Technical Meeting on Vehicle Technology, IEE $J$ 2011(14), 7-12, (2011)

8) R. Madhavan, Student Member, IEEE, B. G. Fernandes ICEM (2010) Rome.

9) N. Matsui and Y. Takeda: J. IEEJ. D, 118, 685 (1998).

10) S. S. Ramamurthy and J. C. Balda: IEEE Trans. Ind. Applicat, 37, 1256 (2001).

11) K. M. Rahman, B. Fahimi, G. Suresh, A. V. Rajarathnam, and M. Ehsani: IEEE Trans. Ind. Applicat. 36, 111 (2000).

12) H. Yagura, H. Goto, O. Ichinokura : Journal of the Magnetics Society of Japan, Vol.33, pp.307-310 (2009) (in Japanese)

2011年10月27日受理，2011年12月16日再受理，2012年2月3日採録 